\title{
Influence of the Independence of Directors and the Combination of CEOs with Chairperson on Firm Value: Evidence from Cote d'Ivoire
}

\author{
TUO Siele Jean ${ }^{1 *} \quad$ Li Chang $^{1} \quad$ Guy Roland Assamoi $^{2} \quad$ Mebrahtu Tesfagebreal $^{1}$ \\ Morié Guy-Roland N'Drin ${ }^{3}$ \\ 1.School of Accounting, Dongbei University of Finance and Economics, 217 Jianshan Street, Dalian, 116025 , \\ PR China \\ 2.School of international economics, Dongbei University of Finance and Economics, 217 Jianshan street, \\ Dalian, 116025, PR China \\ 3.Center for economics research, Shandong School of Development, Shandong University, Jinan, 250100 China \\ * Email of the corresponding author: tuosiele88@gmail.com
}

\begin{abstract}
Many empirical studies have been conducted to test the impact of the characteristics of board of directors on the performance of stock exchange listed companies in developed countries and emerging countries. There are no abundant literature on the impact of independence and Chief Executive Officer (CEO) duality on corporate performance in Cote d'Ivoire. Cote d'Ivoire is a developing country and according the International Monetary Fund (IFM), one of the three biggest economies in West Africa. Analyzes of developed economies are an example for developing economies countries and more a road map for poor countries to the development. However analyzes of the economies of developing or poor countries constitute a diagnostic and motivation to better lead these countries' economies to the development. The aim of this study is to determine the effect of the board of directors' characteristics on the performance of non-financial companies in Cote d'Ivoire. In particular, we focused on the analysis of three characteristics: board size, board independence and the duality of the CEO. Our empirical study has been conducted on a sample of 25 non-financial listing companies for a period from 2002 to 2016 using multiple regression analysis. The modeling was carried out after controlling multi-colinearity and correlation test by using the Hausman specific test, heteroskedasticity test. By controlling variables such as firm size, board meeting and leverage, our empirical results show a positive impact of board size on firm's performance. It is also found that board independence has a negative effect, while CEO duality has a positive effect on financial performance proxied by ROA. However, when performance is measure by ROE, board independence has a positive effect, while CEO duality has a negative effect.
\end{abstract}

Keywords: Board of Directors, Corporate Performance, Board Size, Board Independence, CEO Duality.

DOI: $10.7176 / \mathrm{JESD} / 12-12-04$

Publication date:June $30^{\text {th }} 2021$

\section{Introduction}

Board of directors is the one of corporate governance mechanism which resulting from general term governance. For that this first chapter reviewed a theoretical corporate governance and a theoretical background of board of directors by exhibiting the objectives of this study, research questions and hypothesis, and finally the innovations of this study. Nowadays it is absolutely impossible to talk about board of directors without defining corporate governance because these two concepts go hand in hand. According to the dictionary "Le Petit Robert", the term "governance", born in the 13th century, applied to the bailiwicks of Artois and Flanders. It comes back to us by the English "governance" during the 90s on a concept rather complex and still quite abstract in fact. Indeed, governance is sometimes-controversial concept, because defined in diverse and sometimes contradictory way.

World Bank offers a broad definition of this concept: "We define governance as the set of traditions and institutions by which power is exercised in a country with the goal of benefiting all." This definition is interesting because it links the exercise of power to the search for the common good. This idea of general interest, of common good, is therefore, in this context, at the heart of this definition of governance. The European Commission defines governance according to the own development context. However, this definition can be used in general context. Thus, for this institution: "The notion of" governance "refers to the rules, processes and behaviors that influence the exercise of power at European level, particularly from the point of view of openness, participation, responsibility, efficiency and coherence ". To be clear, this definition presents elements that will become central for many authors, namely the notions of rules, processes and behaviors. Moreover, the concept of participation is very present in this definition and this notion is related to the notion of accountability. However, despite the multiplicity of utilization of this word, it seems to cover topics close to "good governance". For people in public or private sector who use this concept, it refers primarily to a movement of "decentralization" of reflection, decision-making and evaluation, with a multiplication of places and actors involved in the decision or construction 
of a project. There are two main types of governance: corporate governance for private sector and political governance for political and administrative thinking. Political governance is generally associated to global or world governance, territorial or local governance according to the scales of governance approached. The word governance refers also to the implementation of new modes of steering or regulation more flexible and ethical, based on an open and informed partnership between different actors and stakeholders. Thus, corporate governance is defined as the set of rules that determine how a business is managed and controlled. Aguilera and Jackson improved this definition; according to them, corporate governance describes the structure of rights and responsibilities among people who have an interest in a company (Aguilera and Jackson, 2003). For them corporate governance is the set of processes, customs, policies, laws and institutions that affect how a company is run, managed, or controlled. It is consistent with the definition given by the UK's Bradbury committee in January 2000. The committee defined corporate governance as the system by which companies are directed and controlled (Bradbury, 2000).

One of the main goals of corporate governance system is to improve shareholder wealth because an effective corporate governance system can help ensure an appropriate allocation of wealth and power among shareholders (Mccconomy et al., 2000). There is a positive relationship between good corporate governance and good corporate performance. Corporate governance seeks to balance the interests of shareholders with those of other stakeholders and emphasizes corporate social responsibility. Ensuring better corporate governance practices in companies will increase investor confidence as investors believe that a company with good corporate governance can reduce risk and attract more investment (Arawak and Knoeber, 1996). The main objectives to be achieved are good economic governance, a favorable legal and regulatory environment, strong supervisory bodies with enforcement powers, a capacity for self-monitoring of compliance with rules, a strong and well-formed board of directors balanced, as well as accurate and timely disclosure of information. It is now well recognized that corporate governance plays an important role in strengthening the value of the business (Erickson et al., 2005, Cho and Kim, 2007). The governance of the company aims to maximize value for all stakeholders. Note that in a wider acceptance, a stakeholder is any actor who is concerned by the smooth running of the company. As a result, it encompasses not only all those who participate in the contract node, but also those who may experience negative externalizes as a result of the company's activity (Stieglitz J., 2007). Thus, in the context of corporate governance (stakeholder governance), the interests of all partners are taken into account. From this perspective, the company's performance is no longer only appreciated in the sole interest of shareholders, but in comparison with those of all partners (stakeholders).

In the same perspective, this study tries to verify the applicability of this definition in the general context of Africa and the particular case of Cote d'Ivoire. Corporate governance does not only play the role of balance between various stakeholders interests in African companies but is also an imperative for large African companies. However, Bakari Traore in his booklet in 2011 entitled "Decouvrir et comprendre la Gouvernance", defined the concept of governance, and explained how it is necessary to reduce the governance deficit in Africa. He presents the different indicators of public governance used around the world and focuses on corporate governance indicators and codes. As a result, according to him in 2015 , corporate governance has become a necessity to guarantee the sustainability of companies. In Africa, and particularly in the OHADA space, many companies do not yet practice corporate governance. However, there is a growing interest of companies for an ethical approach and social responsibility that are essential factors to establish the good reputation of the company and give it sustainable access to markets, sources of financing and sites of business. Nevertheless, the debate on corporate governance is based on the following hypothesis: leaders are able to overcome the mechanisms put in place to control them, business leaders are pension to the detriment of shareholders and other partners of the company (stakeholders). We must recognize that the debate on corporate governance is part of a current of thought from the United States, where leaders have strong power against a dispersed shareholding. In fact, it is a question of seeking the conditions that will ensure the running of shareholder governance prioritizing the interests of shareholders in the strategic decision-making process. Thus, such a conception of corporate governance is part of an Anglo-Saxon trend that places shareholders at the center of the system.

However, it must be emphasized that even though governance has several other elements, they are all linked to the board of directors. This is more visible with this OECD definition that the governance is a set of relationships between a firm's board of directors and its shareholders and other partners. That said it is clear that the OECD through this definition shows the importance acquired by the board of directors in the system of corporate governance from the particularities of these institutions and the specificity of their governance. In addition, the theories of governance still release the problem of interests between owners and managers, hence the intervention of the board of directors. To this end, the board of directors plays a key role in the company management; in that sense, these characteristics could be the main evidence of companies' performance. In fact, the board of directors is the organ of decision-making power of an organization or a company because it makes the decisions concerning the policy of the organization or the company, adopts the program and the budget of these before it is submitted to the General Assembly. 


\subsection{Research background}

In West Africa especially in Cote d'Ivoire, private and public corporate have proved to be enormous financial gulfs, highlighted by the economic crisis that appeared in the 1980s. Among measures used to redress them, privatization occupies an important place. However, all public corporate in a country cannot be privatized, and also some privatizations do not achieve the expected results. Therefore, it becomes essential to ask the causes of failures of African public companies to better treat them. In line with this, our study tries to understand the reasons of the poor or good performance of a sample of companies listed on the stock exchange in Cote d'Ivoire. For this purpose, the board of directors which the main corporate governance mechanism, is studied of the point of view of its characteristics, composition, role, structure and processes. The main tasks of the board of directors are: determining the strategic direction of the firm or activity, ensuring that they are implemented in accordance with its internal regulations, approving the accounts, appointing the president, determining the agenda of the general meeting. The board of directors, in the logic of agency theory, develops incentives and constraints to influence positively the management of business and thus improve its performance (André Marie Mbini Oneida., 2015). However, faced with the good results produced by the managerial approaches of the firm, the agency theory developed by Jensen and Heckling was a weapon of the counter-offensive launched by the ultra-liberal economists to legitimize the vision of a firm owned exclusively by its shareholders. Nonetheless, others definitions taking a step back from this conception of corporate governance have been developed. This is the case of Berle and Means (1932) who argued that the objectives of shareholders and managers in a firm may differ in the management thereof. Thus, this statement supports the idea that a company that opts for managerial approaches is less efficient compared to companies whose capital is concentrated in the hands of a single owner. In order to limit the power of the leaders and to discipline them, some shareholders will refer to corporate governance theory, developed in agency theory and dealing with all internal and external mechanisms to the corporate in order to counter the leaders to manage the firm in accordance with their objectives. Thus, for Chateaux G.(1997), "corporate governance covers all the organizational mechanisms that have the effect of delimiting powers and influencing the decisions of managers."

In fact, board of directors is an internal mechanism of the company and is also the work of studies on corporate governance by relating these characteristics and the company's performance. The agency theory defines board of directors as the primary internal mechanism for controlling officers, assuming that the internal directors do not have enough power to oppose the decisions of the directors and therefore the independence of certain outside directors, independent of management, would allow them to oppose the most questionable decisions (Weisbach 1988, Eisenstein \&amp; Wyatt 1997). Similarly, the main argument put forward against the agency's theory is to evoke the idea that shareholders are not the only ones to be concerned by the evolution of the firm's activity. Other actors are stakeholders, either through contractual relations or simply by the impact of the firm's activities on its environment. Thus, a step in the right direction would be require companies to consider all stakeholders, in addition to their shareholders. Thus, stakeholder theory and expectancy theory (RK Mitchell, BR Agle and DJ Wood, 1997) support the agency's theory by emphasizing that the board's function goes beyond simply defending the interests of shareholders originally intended. The agency theory includes the objectives of the different parties in relation with the firm (suppliers, customers, employees, creditors, state ...). In addition, the specificity of the assets to be secured and the need for efficiency desired by resource providers have progressively enriched board of directors framework through the costs of transaction theory and the theory of the dependence on resources. Indeed, firstly the agency theory established a positive relationship between the independent directors proportion and the corporate performance. Secondly, the theory of stakeholders and expectations supports that the separation of duties of the board of directors chairman and the Chief Executive Officer could reduce agency costs and thereby improve corporate performance. These theories support the idea that the impartiality of supervision is no longer guaranteed, since due to the confusion of competences and responsibilities. The CEO-chairman becomes judge and party and thus this cumulative role makes difficult the identification of the responsibilities of the Board of Directors chairman and those of the Chief Executive Officer in the event of company poor performance.

The empirical results of previous studies of corporate governance and board are as varied as supportive theories. However, in direct contradiction with agency theory, the theory of stewardship supports the idea that leaders are trustworthy, so these leaders are not opportunistic and act in the interests of the company. This theory calls into question the independence of the directors present on the board of directors by granting an influential role to the directors in the board because their presence in board of directors can be justified by a contribution of specific knowledge of the board of directors. Some studies have found a positive significant relationship between duality of the CEO and performance, which implies that the combined leadership structure is associated with better corporate performance than those with an independent leadership structure (such as Davidson et al., 1990, Donaldson and Davis 1991,Brinkley et al. 1997, Coles et al. 2001, and Tian and Lau 2001. Lin, 2005). In other words, this hypothesis verifies that companies that opt for a cumulative functions structure has a better perform than those that choose the separation of these two functions. Always in verification of this hypothesis, the theory of stewardship advances a logical reasoning according to which the leaders have specific knowledge of the company because they have company experience, sot his good knowledge of company is very useful for decision- 
making by increases its performance. In sum, the defenders of duality are mainly related at the cooperation theory to the theory which according duality leads to a superior performance because it allows to have a clear leadership. It mean the separation of functions dilutes the leader power and increases contradiction likelihood between stakeholders, board of directors and the expectations of the executive.

In reviewing the relationship between independent board members and corporate performance, it should be noted that the vast majority of empirical results from previous studies are positive (egVo\&amp; Nguyen, 2014), but some empirical studies found a negative relationship between these two variables. (Vistula et al., 2015). Similarly, empirical results for the relationship between CEO duality and corporate performance are also mixed; some indicate a positive relationship (for example, Gullet et al., 2013), some studies have find a negative relationship (eg Daily \&amp; Dalton, 1994 and Cornett et al., 2008), and others studies haven't indicate any relationship between these two variables (for example, Daily \&amp; Dalton, 1992, Abdullah, 2004 and Chen et al., 2008). These results are mixed because it is likely that there are endogenous variables affecting relationships that haven't been taken into account in previous studies or because the level of governance in the locality on which the study is being conducted.

In recent decades, a crushing amount of research on CEO duality has been conducted in the context of developed economies with sophisticated financial and legal systems, with an important attention paid to the impact of CEO and a strong board of directors on corporate performance. Few studies on this topic have been conducted in developing countries. Our study analyzes the impact of the characteristics of the board of directors on the performance of non-financial companies in Cote d'Ivoire which is a developing country.

\subsection{Problem statement}

Generally, it is recognized that corporate performance has become a significant source of external finance and investment in developed and developing countries. Indeed, board of directors of the listing companies are been the subject of much criticism during the 1980s and 1990s following a series of failure and the poor performance of these listing companies that occurred during those years. Many studies have trying to explain that poor performance on showing the importance of the board of directors on corporate performance (ROA and ROE) by their analyses using board size variable (the number of board members), board composition variable (number of independent directors in the board) and CEO duality variables (board chairman is the CEO). The studies using these characteristics have concluded that some of the board size and board composition framework have a positive impact on corporate performance (Hediye Sadat Mirsharafoddini, 2014). On the other side, Nur Hidayah BintiLaili (2014) and Panya Issarawornrawanich (2015) thought that CEO duality have a negative effect on corporate performance. As suggested by previous studies, several factors leads corporate performance in the developed countries. However no more attention is devoted to this situation in the West Africa countries, and particularly in Cote d'Ivoire. Although the government made great efforts to encourage corporate governance. The question is what are the real impact of the board of director's characteristics on corporate performance? What are the factors which favor good corporate performance in Cote d'Ivoire? Thus, our analysis is to investigate in addition to the key role of the board of directors, the others factors that affect Cote d'Ivoire non-financial listing companies' performance from 2002 to 2016.

\subsection{Research objectives and Questions}

This research is designed to achieve specifically the following objectives:

A. To find out if there is a positive significant relationship between the sizes of the board and corporate performance in Cote d'Ivoire.

B. To find out if there is a positive significant relationship between board of director independence and corporate performance in Cote d'Ivoire.

C. To find out if there is a significant negative relationship between CEO duality and corporate performance in Cote d'Ivoire.

D. To show the role of the board director in the company management.

Based on three objectives stated, this study attempts to find answers to the following specific questions that constitute our research questions:

I. Is there any positive relationship between board size and corporate performance in Cote d'Ivoire companies?

II. Does independent directors have any positive relationship with corporate performance in Cote d'Ivoire companies?

III. Is there any negative relationship between CEO duality and corporate performance in Cote d'Ivoire companies?

1.4 Research hypothesis of study

In order to answer our different research questions, the following hypothesis are presented: 
Hypothesis $1(\mathrm{H} 1)$ : Board size has a positive relationship with corporate performance.

We hypothesize that there is a positive significant relationship between board size and company performance following (Baysinger and Butler 1985), who concluded that the size of the board of directors has a positive incident on Nordic Listed Firms performance.

Hypothesis 2 (H2): Independence of the Board of directors has a positive relationship with corporate performance. We hypothesize that independent directors have a positive significant connection to the corporate performance according to authors Jackling \& Johl (2009), whose the results reveal that independent directors can add potential value to the company's financial performance.

Hypothesis 3 (H3): CEO duality has a negative relationship with corporate performance.

We hypothesize that there is a negative significant link between the CEO's duality and the corporate performance after Robert W. Rutledge, KhondkarE. Karim and Siyu Lu who concluded that there is a negative relationship between the duality of the CEO and the corporate performance, from a study on the NASDAQ-100 index with controls for endogeneity.

\subsection{Contribution and Innovation of the study}

One of the main motivation of this study is to explore if the duality-management structure and board independent work well in West African countries especially in Cote d'Ivoire companies which is a developing country. At the same time this study will help local and foreign investors, lenders/financiers in knowing about corporate governance conditions, economic conditions, board features and help investment to know how and when to do the financing. It will serve as a reference for Cote d'Ivoire and some west African countries companies to know the real problem and advantages that they are face on corporate governance when they choice the board of directors as their corporate governance mechanism. That could allow them to implement board of director's characteristics which will lead to efficient in corporate performance. Since it's one of the first study carried out on board of director's performance in the companies on Cote d'Ivoire, it will add literature to the explanation of the roles of the board of directors in corporate performance and corporate governance. This study contributes also to the documentation of the role of corporate governance mechanism practice in Cote d'Ivoire. One of the main contribution of this study is the verification of this statement in Ivorian context on testing hypothesis constructed from the empirical administrative literature concerning the impact of the board of directors (composition, size and direction) on the performance of listed companies of Cote d'Ivoire. This paper contributes to examine the board structure issues and their impact on Cote d'Ivoire firm performance and help companies in term of improving their corporate performance factors in order to benefit more from the board of directors. This study contributes to the identification of certain weaknesses of the board of directors and also promotes the strengths of the board of directors. At the same time, helps to understand the effectiveness of corporate governance mechanisms across their board of directors.

The remaining part of the study is summarized as follows: chapter 2 presents the literature review and theoretical framework of this study, chapter 3 presents and defines direction variables of the board of directors, as well as the performance variables and describes the methodology used for analysis. chapter 4 presents discussion and analysis of the results. And finally, chapter 5 presents conclusion and recommendation of the study.

\section{Theoretical Framework and Literature review of the study.}

\subsection{Theoretical aspect of the board of directors}

It is largely known in the empirical literature that the main internal mechanisms of corporate governance are the board of director and the ownership structure. This study is focus on the board of director and corporate performance, but before study exploration, it is essential to underline that the previous results of the relationships between board of director characteristics and corporate performance are often totally contingent or partially contingent. In the Cadbury Report of the United Kingdom (Cadbury, 1992, p.15), he defined corporate governance as the "system by which enterprises are directed and controlled", including the practices and composition of the boards of directors and their relationship with the firm performance.

However, researchers see the problem of corporate governance as a conflict between shareholders and management. In fact, in modern societies, ownership and management are separated from each other and therefore managers make decisions on behalf of shareholders, which creates an agency problem. Managers are looking for personal interests because the real owners-shareholders are absent, this leads also to an agency problem. Nevertheless the board of directors of a firm should accomplish the essential duty of surveillance and guidance of the high direction (Drobetz et al., 2013). The role played by the board of directors in the supervising management area and the board area are to improve the company's performance and this role still at the heart of the corporate governance literature. Rose (2005) argues that the board plays a key role in controlling of the direction and aligning these interests with shareholders' interests. It means that a board improves the firm performance and establishes legal responsibilities and fiduciary duties. Hermalin and Weisbach (2003) argue that a smaller outsider in the boards are more efficient in supervising management and thus better serve the shareholders' interests. 
Some researchers assume that when the ownership is separate to the management, the managers (agents) will not align their interests in the business with those of owners, because they are motivated by their own interests. The managers are engaged in selfish activities that may be detrimental to the economic welfare of the main (shareholders) when there is no monitoring (Deegan, 2006, p 225). To solve that, (Zahra and Pearce II, 1989, Bathala and Rao, 1995, Nicholson and Kiel, 2007, Kaymak and Bektas, 2008) argued that boards of directors composed of independent outside directors can avoid the agency problem by being able to monitor any selfinterested actions by managers. (Luan and Tang, 2007) support that and saying the separation can improve the company's performance. However, the agents will be motivated to work only in the owner interests if there is an oversight incentive in the form of independent directors who set the tone for less opportunistic behavior on the part of managers. It means independent outside directors may provide more skills and knowledge for the benefits of the company.

\subsubsection{Agency theory based on corporate governance and board of directors}

MC Jensen and WH Meckling (1976), founders of the agency theory, were originally inspired by Alchian and Demsetz, to define the firm as a node of contracts, that is to say the association or mixing of contracts. According to them, the model that explains the financing and shareholding structure is based on information asymmetry hypothesis and interest conflict between the owner-manager, the new shareholders and the financial creditors. Thus there is an agency relationship, whose the existence an agency theory. Indeed, for Jensen and Meckling "there is an agency relationship when a person uses the services of another person to perform on his behalf any job". In this case, the agency relationship is between the main (shareholder) and its agent (manager), where the manager takes engagement to serve shareholders' interests. Therefore, in these relationships, the notion of agency cost appears, that cost who result from the potentially opportunistic character of the actors (moral hazard) ${ }^{1}$ and the asymmetry of information between the co-contractors (adverse selection) ${ }^{2}$. The costs generated by this situation (agency problems) constitute the agency costs ${ }^{3}$; they represent the loss of value compared to an ideal situation where there would not be asymmetry of information and interest conflict. According to the agency's theorists, an organization is efficient if it minimizes agency costs.

According to the analysis of Alchian and Demsetz then of Jensen and Meckling, when the direction and the property are assumed by one and the same person, the optimal efficiency situation is achieved. In the opposite case, the shareholders, exposed to moral hazard and adverse selection resulting from the growing autonomy of the manager, do not have the full assurance that manager will optimize their capital. That means the maximization of the return on equity is low, when the share of the company capital owned by manager is small. Therefore the relationship between shareholders and managers is necessarily a conflict relationship based on divergence of interest. There are three kinds of interest divergences:

Divergence between shareholders and managers for making some decisions

Divergence on risk perception

Divergence about the benefits that leaders receive from their position.

Based on hypothesis of agency theory and on the recognition of the central role of the manager, two main definitions of governance can be evoked: According to Shleifer and Vishny in a financial traditional approach," the governance of company studied the different means use by the company's capital providers to ensure their return on investment." In a restriction vision of governance, another definition according to Charreaux, "corporate governance can be defined as the set of mechanisms (organizational or institutional) that governs the decisions of managers and defines their discretionary space." This definition makes it possible to include logically idea of Jensen and Meckling according to which the main force of control, internal, to delimit the discretionary space of the mangers is the internal control system managed by the board of directors with these independents directors.

To resume, the agency's theory is talking about corporate governance across the board of directors. It emphasized the disciplinary role, the supervisory role and the control role of the board of directors and mainly the interest conflict between shareholders and managers, to defend this thesis on the board of directors. This theory defends the independence of the board front the leaders and the large size of the board of directors but is opposed the idea of cumulating the functions of CEO and board chairman.

\subsubsection{Stewardship theory based on corporate governance and board of directors}

The stewardship theory approach presents a new light on the corporate governance, giving a different

\footnotetext{
1 - Moral hazard ex post is when main (shareholder) is never assured that the agent (manager) makes every effort to execute the contract and does not pursue its own objectives.

${ }^{2}$ - the adverse selection ex ante is when agent has information whereas the main do not has it, and thus he can hide them before signing the contract.

3 - Monitoring expenditure : these are the costs support by shareholders to ensure that agents (manager) manage company in accordance with their interests

- Bonding costs: these are the costs support by the agent to make shareholder on trust that the company is manage accordance with their interests.

- Residual loss: these are the costs inherent to the divergence of interest between the manager and the shareholders (poor allocation of resources, choice of a non-optimal strategy, etc.).
} 
understanding of the human and social relationships within organizations (companies).

This theory refers to the way of conceiving and creating value. Thus for stewardship theory, agency theory considered individual like a calculating agent who searches in all circumstances, looks for "maximizing" his own interests (or to promote his own preferences at detriment of others). The "stewardship theory" approach at contrary, considered that the objective of management is not to make a profit of some economic actors or to strengthen the reputation of some economic actors. According to that theory, manager aims to create the richness, in sharing it in a balanced way. For this perspective, an integrative and collaborative approach is preferable than a domination strategy based on the control of the other party. It means, it may be better sometime for a manager to be altruistic with the others organizations actors than adopted a disciplinary dimension in the relationship between individuals to solve the company internal conflicts. Indeed, the stewardship theory supports the altruism idea that it defined like a utility function that links the satisfaction of an individual with others person. This theory show us that in specific situation, altruism can also use to reduce agency costs (coordination, control, etc.). The "stewardship theory" approach is more focus on the psychology of actors, on their responsibility, sense of duty and the cooperation (trust relationships). According to this theory, this vision must not be necessarily associated with a form of naivety but rather with the common interest ethic.

To summarize, the stewardship theory is an entire contradiction of agency theory, in its definition of corporate governance and the board of directors. It emphasized the leader's altruism behavior, his good morals and his good knowledge of the corporate environment, to defend this thesis on the board of directors. This theory supports the non-need of independence directors, the small size of the board of directors and especially the idea of cumulating the functions of CEO and Chairman of the Board. In conclusion, there are divergent views of corporate governance and board of director function between these two theories. Indeed, while the agency theory privileged an economic and financial conception around two strong ideas: the individual is selfish and opportunistic, which requires the setting up of control and monitoring systems (board of directors). The stewardship theory present a new management approach of relationships in organizations and a different approach of the risk by highlighting other issues and objectives in the relationships between individuals, which often going well beyond economic considerations. Specifically, this view of the organization assumes that the interests of the main (the one who decides and delegates) and the Agent (the executing one) are compatible, thus reducing agency problems because the agent act in the direction of the main (interdependence strategic). Therefore the Governance becomes a cooperative game, where the confrontation becomes the preferences and interests alignment.

\subsection{Hypothesis 1, board size has a positive relationship with corporate performance}

The number of directors in the board constitutes the size of board of directors. The composition of the Board of Directors has been long-time of particular interest to researchers and theorists of corporate governance. Board size and board composition can be an important factor of the performance because the study of this factors makes it possible to evaluate, on the one hand, the efficiency of the good functioning of the board of directors, and on the other hand its capacity to have an impact on the performance, on the voluntary disclosure on the management of results. It is in this logic that some authors like Khamoussi Halioui (2013) argued that a large size of the board of directors may improve board efficiency and improve also the company's financial results by helping management to reduce agency costs resulting from poor management. In the relevant literature, although many studies have examined the relationship between board size and company performance.

Indeed, many researchers like Belkhir (2006) and Kwan (2003) have emphasized the positive effect of a large board size. For them, the capacity added to larger boards can be more important than the increasingly problem of communication, of coordination and decision-making issues. Chouchene and Ibtissem (2010) stipulated that the small board can be easily controlled and influenced by the managers, while the larger board presents a variety of experiences belonging to different board members so difficult to be controlled by the managers. The large boards are perceived as leading to better corporate performance by some researchers, because of the wide variety of skills present for better decision-making and to monitor the performance of the CEO. For example, Adams and Mehran (2005) found a positive relationship between the board size and companies performance of U.S. In addition, Jameleddine Mkadmi and Khamoussi Halioui (2012) have also reported that the large boards are associated with better performance. These results support the conclusion made by Ahmed Fernandez et Arrondo (2005) regarding the relationship between board size and firm performance when they said that firm with large board of directors ensure a better performance. The positive relationship of board size and company performance can be report again by the fact that, the monitoring capacity of the board increases simultaneously with the adding of new directors. This can be more understand with Manel Kolsi \& Hanen Ghorbel (2011) argued that a large board size should be preferred to smaller size because the possibility of specialization for effective monitoring and advisory functions. Here, the author claimed that the size of the board has a positive impact on firm performance, it means a large board size provide a better corporate performance. (Arslan, 2010) found a positive impact of board size on the stock market performance of the firms. In the same direction, A. Schatt (2005) and Abidin (2009) in their studies have found that companies with a large board provide better performance. 
Board with a large number of directors provides enough people to more easily manage the work load of the board, the responsibility is divided very well between his many members and larger size provides more perspectives .Godard and Schatt (2004) argued that higher is the number of directors, higher is the company performance. Andres and Vallelado (2008) found that larger boards were more effective in monitoring and create more value for a firm. Larger is the board, the greater knowledge of the various administrators can improve performance and to exercise effective control (Coles et al., 2008; and Linck et al., 2006).Ahmed Zemzem and Abderrazak Ellouz (2016) argues that boards of directors comprises more than average better performs and help the company to gain a competitive advantage and eliminate the externalities that negatively affect the company.

\subsection{Hypothesis 2, independent board of directors has a positive relationship with corporate performance.}

Board composition has been highly debated in the areas of economics, organizational science literature, and finance on the empirical and the theoretical levels. The board of directors is composite of two different types of directors, the executive and the non-executive. The executive directors are responsible for the day-to-day business of the company, they are directly responsible for business functions such as finance and marketing (Weir and Laing, 2001). An independent non-executive director is defined as an independent director who has no affiliation with the firm, except for his or her director mandate according to Abdoulkarim Idi Cheffou (2014). However, we focus in particular on the independence of the board of directors and its structure for identify the interaction between board characteristics and corporate performance. According to Berghe and Baelden's (2005) analysis, board independence question is an important factor to ensuring board effectiveness through the monitoring and strategic roles of directors.

Pursuant with the teachings of agency theory, external administrators are more performing than internal administrators in conflict resolution and agency cost reduction and moral hazard issues (Fama, 1980). Indeed some previous researchers such as Deutsch (2007) and Philippe Xavier et al (2011) argue that the independence of the board of directors is resulting to a high performance for the company. On supporting the premise of agency theory, they mean that non-executive directors playing an important role in effectively solving the agency problem and their presence on the board can lead to more effective decision-making and should drive directly firm to better performance. From the same point of view, many researchers have find a positive relationship between board members independence and firm performance such as Marchetti (2009) and Fabrice Galia (2013) who have found a positive association between the proportion of independence board members and firm performance.

The independence of the directors is the most important attribute of the board allowing a better control of the direction and limiting the managerial discretion, according to Nowak and McCabe (2008). Indeed, a board of directors which is independent from the management allows a better control of the activities of the firm and the decision-making process, without favoring the personal interests of the leaders. Géraldine Broye (2012) also support that on saying it allows effective control over the process of producing financial information to reduce the extent of results management. In the same vein, Ahmed and Duellman (2007) consider that the independence of directors ensures the incorporation of bad news into results in an opportune time and therefore leads to a better quality of the produced financial information.

Some authors such as Dahya \& al. (2008) and Yves Moulin (2012), concluded that independent external directors contribute positively to effective management control of the managers to improve firm performance, because, in general, the reputation of these directors in the senior managers' labor market is their incentive to act in the company interest. In this way, Fama (1980) argues that external directors act in the company interest to get new mandates. Fabrice Galia and Emmanuel Zenou (2013) have found a positive stock price reaction at the announcement of the appointment of independent director. They can argued this result by the fact that this announcement leads necessarily to rise company market stock prices in the days after this action undertaken by the board of directors, because investors hope a better performance at the arrival of new independent director. It implies that the proportion of outside directors affects shareholders' wealth, so firm performance. By sharing this junction, Liang \& Li (1999) conclude on a panel of Chinese companies that the presence of outside directors in the board generates an increase of returns on investments undertaken by the firm. Uadiale's (2010) study revealed also a positive association between independence directors sitting on the board and corporate financial performance. She suggested that the composition of outside directors as members of the board of directors must be sustained and improved. Fich\& Shivdasani (2005) reported that the proportion of independent directors on the board has a positive effect on the company's financial performance measuring by Tobin's Q in the UK. Jackling and Johl (2009) have also found a significant and positive relationship between independence of the board of directors and financial performance. Cotter \& al. (1997) conclude that independent directors must to occupy more than half of the seats of the board of directors because this policy increases shareholders' dividends and therefore their wealth. Chen and Kao (2004) show that a high proportion of independent directors in the board of directors improve financial disclosure quality and financial performance of companies. However, Dehaene et al. (2001) found a significant relationship between the number of outside directors and return on equity, which supports the view that one third of the party are able to perform a supervisory function because of their independence position 
and shareholders' interests should be protected well. Black and Rachinsk (2006) and Lefort and Urzua (2008) show that increasing the number of independent directors in the board contributes positively to the financial performance of the company. Zainal Abidin et al. (2009) find evidence that a higher proportion of non-executive independent directors on the board of directors have a positive impact on the firm performance based on intellectual added value coefficient measurement. Kor\&Misangyi (2008), by leading an application on a sample of 78 firms over the period 1990-1995, approved that independent directors have good skills to impact positively corporate performance.

Others authors, such as Schiehll \& Bellavance (2009), also approved that independent directors promote better value creation within the company than internal ones. This idea is already corroborated by Sarkar \& Sarkar (2009) who, by conducting a study on 500 companies listed on the Bombay Stock Exchange in India, conclude that an independent director in the board of directors favors the creation of value because independents managers companies provide a better governance compared to internal ones. Lin \& al. (2009) agree with this idea as well as the subsequent conclusions and point out that corporate governance intervened through its mechanisms to neutralize agency costs, to protect all of stakeholder's interests, enable shareholders to increase their investment and therefore achieve a high performance.

\subsection{Hypothesis 3, CEO Duality has a negative relationship with corporate performance.}

The CEO is the Chief Executive Officer of the company and by priority he is the most important individual of a company, who is the final authority with regard to decision-making and strategy formulation. The duality of the CEO means two jobs performing by only an individual, which means the only person assumes the additional responsibility to lead the Board chairmanship in addition to that of CEO. According to Zona et al. (2015), CEO duality is the responsibility distribution at the same person as CEO and chairman of the board for the same period. This means nominated the same person, over the same period, to the positions of Executive Director and board Chairman. According to Kaymak \& Bektas (2008), the independence of the board of directors is not the only catalyst to improve firm performance.

The defenders of the agency theory advocated that the combination of the functions of the board of director's chairman and the chief executive officer, creates a divergence between these personal interests and the shareholders' interests of the company and that leads to increase agency costs and increase the abuse of power. Crespí-Cladera and Pascual-Fuster (2014) as advocates of agency theory believe that separating the roles of chairman and CEO leads to a deepening examination of managerial behavior and thus leads to better performance. For them, results management and results fraud are more frequent in boards that opt for dual functions, therefore the separation of the roles of board chairman and CEO increases the control of the accounting and financial process and results in quality financial information. The results of a study of Hwang and Kim (2009) are been confirmed by another study of Tate (2012) who found that return on assets (ROA), is naturally very low in the company governed by a CEO who is himself the chairman of the board of directors. These results are profoundly proven in 1999 with Rechner, P.L., Dalton, D.R., (1999) who indicated that in periods when financial returns were high (1978-1980), companies without duality had better performance than companies with duality, Nguyen (2012) summarize that CEO duality is the absence of separation of management and control decisions, so the board can be unable to monitor and evaluate effectively the chief executive officer. As a result, the separation of the CEO and Chairman of the Board will improve the company's performance, Fodil et al. (2007). Advocating for the separability thesis, Bhagat \& Bolton (2008) conclude that there is a positive and statistically significant relationship between non-accumulation functions and firm performance. In their view, the duality of the CEO could affect the board's ability to control management. Djoufouet WulliFaustin (2015) found that the intervention of the CEO on the board of directors, can result in reduced participation and effectiveness of board members in the Cameroonian companies. Kramarz and Thesmar (2013) concludes that the separation of the role of the chairman and CEO leads to a better financial performance of the company. Sarkar et al. (2011) consider CEO duality as an obstacle to the role of the board because it weakens the control exercised by the directors. In this perspective, Lau \& al. (2009) stipulate that the board of directors should be strongly independent to make a decision to improve firm performance. For example in the case of duality, the board of directors is unable to dismiss a CEO who is not performing well.

\section{Empirical Methodology and Model}

\subsection{Data and sample}

Denscombe (2000) argued that there are two main research approaches, quantitative and qualitative research. The quantitative method is used in this study to analyze the secondary data in order to achieve the goal of this research.

The selection of data in quantitative research is a critical and important part of research from the point of view of researchers. The sampling technique used for this study is a non-probabilistic convenience sample because the data was not easily available. The sample of 25 listed companies is selected for this study, which represents the non-financial sector. The data of our sample were collected based on the measurement of our different variables, using the annual reports of the selected companies. The companies cover the market capitalization to a certain 
extent and are listed on the BRVM. The data used for this study are panel data and also naturally secondary. This study used panel data, several endogenous and explanatory variables to analyze the effect of board characteristics on companies' performance in Cote d'Ivoire. Good corporate governance should improve the performance of these companies. To conduct this research, the study used a panel of 25 firms for a period of 15 years (2002-2016) resulted in 375 observations which dependent upon the availability of company annual reports. In fact, based on the availability of the annual reports of the companies, this study takes into account 25 non-financial companies listed on the regional Stock Exchange market (Bourse Regionale Des Valeurs Mobiliere) of Abidjan for the period 2002-2016, which represents $41 \%$ of the total number of listed companies as on 31st December 2016. This is also $60 \%$ of total non-financial companies representing almost $57 \%$ of the market capitalization of total non-financial companies at that date. The non-financial companies represents $69 \%$ of total companies listed on the BRVM. The sample also consists of variety of industries as per the classification of 'Standardized Industrial Classification'. The data required for this research were collected on the website, http://www.brvm.org/fr/repports-societes-cotees, BRVM (Bourse Regionale des Valeurs Mobiliere) of West Africa located in Abidjan (Cote d'Ivoire). Indeed the firm annual reports, the available financial statements have been collected from time to time with BRVM and for some companies; the number of board meetings and the number of independent directors have been collected on the official website of these companies. For this research data are collected from available annual reports of the 25 non-financial companies listed on BRVM for the years 2002-2016.

\subsection{Variables description}

\subsubsection{The dependent variables}

The dependent variable in our model is the firm performance. Firm performance may be accounting or stockmarket. The measures corresponding to each type differ according to two main considerations. The first consideration is that the accounting rate of return is based on the past, while market return depends on the future. The second consideration concerns agents who measure the performance of the firm. The stock market performance considered the psychology of investors who seek to predict possible events under the constraints of insight, optimism or pessimism. While the accounting yield is determined by accountants under the constraints of the standards of their profession and it is not affected by the psychology of investors (Demsetz and Villalonga, 2001).

However, several studies use accounting measures of performance, namely accounting value of the firm's assets and capital, net income, earnings per share, profitability ratios of equity and total assets, for example Sterling HUANG \& Gilles HILARY (2017), Salim Darmad (2011) and Othman Yeop Abdullah (2014). The general disadvantage of these measures is that they can be manipulated by company executives to give a false good image of the financial health of their companies. Nevertheless, the profitability ratio can be considered as the most suitable for measuring performance. It is a synthetic indicator, It then makes it possible to study the firm's performance and its ability to generate profits (or beneficiary capacity). It measures the success of the firm in the use of its investments. Indeed, high profitability shows that these are used productively, generating undistributed profits that increase capital. This allows good growth to thefirm's performance is measured here by using two following ratio:

- Profitability ratio of total assets or Return On Assets ratio (ROA)

This ratio is measured by the ratio of net income to total assets, it's the return on asset. It generally expresses economic profitability. Its main advantage is that it fully covers the activities of the firm but its main inconvenience is that it places all the assets on the same risk plan while the risks relating to the components of the total assets are different. The ROA has been used by many authors such as Blessing Oyinlola (2018), NguyenThi Cam Tu (2017), Chemweno \& EliudCheruiyot (2014).

- Profitability ratio of equity or Return On Equity ratio (ROE)

This ratio is measured by the ratio of net income to equity and it expresses financial profitability. This is the yield from the shareholders' point of view because it highlights the return on their investments. The disadvantage of this ratio is that it can give a biased image of profitability because a high ratio can come from a low level of equity. This ratio was chosen among others by Nguyen Thi Cam Tu (2017), Mrwan Amer\&Aiman A. Ragab (2014) and Attila Balogh (2016).

\subsubsection{The independent variables}

The variables used in this study as independent variables are related to the board of directors. They concern the size of the board of directors, the duality of its management and its composition, namely the proportions corresponding to independent or external directors. We have retained the definitions of these variables as follows:

- The size of the board of directors or board size

Yermack (1996) was one of the first researcher that investigated board size and firm performance and nowadays, almost all authors and researchers cannot investigate board of directors without introduce board size such as Akpan\&Amran (2014), Ironkwe\&Adee (2014) and Ilaboya\&Obaretin (2015). Board size variable (BoaDSIZE) is considered to be the total number of directors sitting on the board of directors and it is measuring by the natural 
logarithms of total number of board members.

- The composition of the board of directors or Independence of board

Board composition variable is the number of independent directors who sitting on the board of directors. We noted that the definition retained for a independent director is the director who is not a leader, a manager, an employee or shareholder holding at least $1 \%$ of the capital of the firm. Also an administrator who is a former CEO of the firm or honorary president, representative of companies in which the firm holds capital shares, as well as director with relationship apparent to the firm's senior managers are not considered as independent directors. This variable is measuring by the ratio of independent directors to total directors. Finally, we note that this variable is the one of the motivation of several investigation on the board of directors (El-Maude, Jibreel Gambo and Bawa Ahmed Bello, 2018).

- The duality of the CEO or CEO Duality

CEO duality is the nomination for the same period of a same person like Chef Executive Officer and chairman of the board of directors for the same period. According to agency theory the same individual is judge and party at the same time. CEO duality variable (CEOD) is considered as a binary, which is equal to value 1 if duality is there, otherwise 0 . This variable has been used by several authors such as Adekunle and Aghedo (2014).

These variables could have provided a clearer and more detailed on the functioning and effectiveness of the board of directors as an internal mechanism of governance but we also include in our models three control variables namely firm size, board activity and leverage.

- The size of firm or Size

Size is the firm size that is measured by the natural logarithm of the book value of its total assets at the end of accounting year. The logarithmic transformation avoids the scale problem that may result from the huge difference with the measurements of the other model variables. This measure has been used in several studies by several authors such as Kwan (2003) who finds that the size of the firm has a positive and significant effect on its performance on suggesting the existence of scale economies. Other authors (Pinteris, 2002, Adams and Mehran, 2003) also find that performance is positively associated with the size firm size. Therefore based on these results, we assume in this study that the size of the firm influences positively its performance.

- Board of directors activity

The variable related to the activity of the board of directors is the number of meetings held. It is measured by the logarithm of the number of meeting held by the board of directors during exercise year, excluding the meetings by telephone call.

- Leverage

Leverage is the debt ratio, which is measured by the ratio of total debt to equity. This is a classic measure of the debt levels that has been used by several authors such as Payal, Dr. Simranjit Singh (2017), Rachd and Moez (2009). Some authors suggest the existence of a positive relationship between the financial structure and the performance of listed firms like Ebrahim, Abdullah, Faudziah and Yahya Ali (2012). This is explained by the governance role assigned to creditors who can force managers to use the firm's funds in unprofitable investments (Jensen, 1993). The following table gives the symbol, the measurement proxy et expect sign of the various variables.

\subsection{Empirical Model}

To examine the effect of the board of directors on firm performance in the case of Cote d'Ivoire, we used the

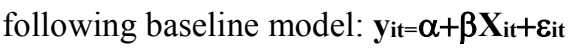

Where $\mathbf{y}_{\text {it }}$ represents firm i performance at the time $\mathrm{t}$, with $\mathrm{i}=1,2, \ldots \ldots . \mathrm{N}$ and $\mathrm{t}=1,2, \ldots \ldots \mathrm{T} ; \boldsymbol{\alpha}$ is a constant term, the model intercept; $\beta$ is the coefficient which measure the influence of the independent variable on the dependent variable; $\mathbf{X}_{\mathbf{i t}}$ represent explanatory variables and $\boldsymbol{\varepsilon}_{\mathbf{i t}}$ is the error term. Following Faudziah Hanim BtFadzi (2012) and several others authors, the model used in this research is related on the following equations.

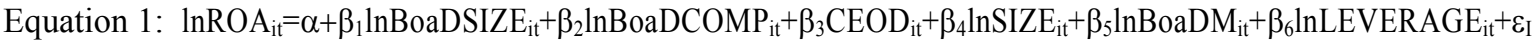

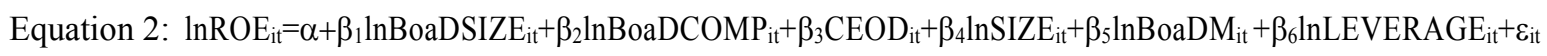

Equations (1) and (2) represent our basic equations, one which we rely to examine the effect of the board of director's characteristics on firm performance that is measured by ROA (Ratio of Net Income / Total Assets) and by ROE (Ratio of Net Income / Equity), as controlling a standard set of financial variables. Indeed, our financial variables are the board of director's characteristics and some control variables that constitute our explanatory variables whose we collect the data following: BoaDSIZE is board size, BoaDCOMP is the number of independent directors, CEOD is the CEO's Duality, SIZE is the size of the firm's, BoaDM is the number of board meetings during the accounting year and LEVERAGE is the ratio debt / equity. For our both regressions equations, In represents the logarithm form, i represents firm's $(1,2, \ldots \ldots ., 25)$, t represents the time $(2002,2003, \ldots . ., 2016)$ ie the years , $\quad \beta_{1}, \beta_{2}, \beta_{3}, \beta_{4}, \beta_{5}, \beta_{6}$ are the unknown parameters, where $\alpha$ is the intercept term or the constant 
that is measures the relationship between the independent variables and firm performance ROA, ROE and $\beta_{1}, \beta_{2}, \beta_{3}, \beta_{4}, \beta_{5}$ are the coefficients of our respective variables, and it denotes the term of error (which contains random or fixed effects) that characterizes the divergence between the observed performance values (ROA, ROE) and the values that would be given to the performance (ROA, ROE) by an exact functional relationship. More clearly it is the error of the model that expresses, or summarizes, the missing information in the linear explanation of the firm values performance. Marion et al. (2012), in his empirical study on firm performance, concluded that there are many models that try to explained firm performance determinants in the firms. However, in order to investigate the impact of the board of director's characteristics, after considering others main determinants, on Cote d'Ivoire Stock Exchange listed companies performance, the study conduct panel data on non-financial listed companies (25) during the period from 2002 to 2016. Like several others this study uses Ordinary Least Squares (OLS) model to establish the nature of the impact of (positive or negative) the board size, independent directors and CEO duality on firm's performance on a sample of 25 non-financial listed companies. We used the control variables according to the previous studies and the data availability. This section aims to describe the econometric method used in empirical literature to analyze the impact of the board of directors on firm's performance in Cote d'Ivoire Stock Exchange listed companies. It helps us to draw the particularity of the model estimated in this study. The study used panel data because, it gives more informative data as it combines the time-series data and crosssectional information following (Hsiao ,2003) for who a panel data is data set which provides multi-dimensional data implying measurements over time. On using Ordinary Least Squares (OLS) model, we have used statistical Stata software. In fact our panel data were analyzed using the descriptive statistics and we tested correlation matrix and multiple linear regression to analyze the board of director's characteristics that impact firm performance in Cote d'Ivoire. First, Least Squares (OLS) model has been used to analyze the determinants of the board of directors that impact firm performance and the impact level. Furthermore, before the regression test, several tests were performed accordingly to make sure that the conditions of using of our model are well verified.

3.3.1 Theoretical model of Ordinary Least Squares (OLS) regression

Firm performance still very useful for investors and shareholders, due to its impact may have on the investment decision making and firm's objectives definition. Firm's performance is nowadays explained by several factors according to the empirical literature, main focus on the board director set up. Further, this means it may have a strong relationship between firm's performance and board characteristics. However, in our research, we are going to point out the statistically relationship between the board characteristics and firm's performance in the selected companies in Cote d'Ivoire. For this purpose, Ordinary Least Square model was used (OLS) to analyze the impact of board of director's characteristics on firm's performance. In fact, OLS model responds to a structural analysis leading by measuring, testing and validating quantitatively the inter-relationships between the variables. Also, OLS model is easy to understand, to run and provide a fact calculation. Yvan Monka (2016).Specifically, in our study we use OLS model to determine, measure, and interpret the impact (relationships) of board characteristics on firm's performance in Cote d'Ivoire. The choice of OLS model for this study is explained by fact that the essential objective of this model consists to establish the statistical relationship between the related variables (dependent and independents). In our case, we are going to analyze the impact of the board of director's characteristics on firm's performance. In the same direction, using OLS model, HoussenRichdi and Moez El Gaied (2009) analyzed the impact of the board of director's characteristics on firm's performance in America. The dependent variables were ROA and ROE and independent variables were also board size, board composition, CEO duality and leverage. ${ }^{1}$ Finally, in order to capture a relevant significance level we used robust test. the results are discussed in chapter four.

\section{Results and discussion}

\subsection{Descriptive statistics}

This study used the econometric technique to estimate panel data by statistical software (STATA 13) for analysis, to estimate the model. Table 2 summarizes the descriptive statistics of all the variables' number of observation, mean, standard deviation, minimum values and maximum values. It is worth noting that table 2 has firm's performance measures that are the return on assets (ROA) and the return on equity (ROE) measure, and all of explicative variables of the model are from Cote d'Ivoire listed non- financial companies. Based on the performance measuring by ROA, there is an important deviation between firms. The percentage mean of the performance ROA is around $40 \%$, with the minimum performance ROA of $-86 \%$ over the period, and the same period firm's performance ROA maximum is 117.8839 with standard deviation of 6.1043 . While based on the performance measured by ROE, there is a little deviation between firms. The percentage mean of ROE performance is around $25 \%$ during the period, with a minimum of -28.2985 and a maximum of 39.5932 .

\footnotetext{
Several models Can be used for the sameresearch objectives (the impact of the board of director's on firm's performance) .GMM :AymenAmmari (2014), OLS Payal and DrSimranjit Singh(2017).
} 
Table 2: showing the summary results of the descriptive statistics of the variables

\begin{tabular}{|l|c|c|c|c|c|}
\hline VARIABLES & OBS & MEAN & STD & MIN & MAX \\
\hline ROA & 375 & 0.3917 & 6.1043 & -0.8663 & 117.8838 \\
\hline ROE & 375 & 0.2410 & 2.8004 & -28.2985 & 39.5932 \\
\hline BoaDSIZE & 375 & 7.5787 & 2.5934 & 3 & 13 \\
\hline BoaDCOMP & 375 & 2.0027 & 1.8622 & 0 & 6 \\
\hline CEOD & 375 & 0.2587 & 0.4385 & 0 & 1 \\
\hline SIZE & 375 & 8.6100 & 1.2900 & 2.2183 & 9.0500 \\
\hline BoaDM & 375 & 2.2293 & 0.9340 & 1 & 5 \\
\hline LEVERAGE & 375 & 1.2400 & 2.5200 & 0 & 3.9100 \\
\hline
\end{tabular}

Descriptive statistics reveal that the size of a board of directors ( BoaDSIZE) of firms from our sample has an average of 7 . In other words, the size of the board of directors is relatively moderate, with a minimum size of 3 members and a maximum size of 13 members and present a standard deviation of 2.5934 . The data show that the board of directors of firms from our sample has in average 2 independent members (BoaDCOMP) with a standard deviation of 1.8622. This implies that boards are less dominated by independent directors in Cote d'Ivoire nonfinancial companies. We can notice it with a minimum of independent director (BoaDCOMP) in these board of 0 and a maximum of 6 independent directors sitting on the board of directors, during the period 2002-2016, this variable has a standard deviation of 1.8622 . The summary of the descriptive statistics of our sample reveals that when the CEO serves as chairman of the board in the same period for the same company, on average there is $26 \%$ incidence of the duality of the CEO (CEOD), with a standard deviation of 0.4385 . It is also seen in the descriptive statistics table, there is in average 2 meeting of the board members (BoaDM) per fiscal years, with 1 meeting on minimum each year and a maximum of 5 meetings each year during the period OF 2002 to 2016.

\subsection{Results of Correlation test}

Table 3 is the overall table of correlation between our two dependent variables and our independent variables. The main purpose of correlation test is to find the nature and the level of correlation between the different variables (to be sure that there is no multi-correlation between all the variables) under study. The correlation coefficient lies between -1 and 1 . A positive relationship is showing by a positive value and a negative relationship is showing by negative values. In fact, when a correlation value is \pm 1.0 , there is a positive or negative perfect relationship (Hair et al., 2010). The values are interpreted between 0 (no relationship) and 1 (perfect relationship). When correlation value between different independent variables is $\mathrm{r}=0.8$ or more, there is directly problem of multi-collinearity.

Table 3: showing correlation results of the variables

\begin{tabular}{|l|l|l|l|l|l|l|l|l|}
\hline variables & $(1)$ & $(2)$ & $(3)$ & $(4)$ & $(5)$ & $(6)$ & $(7)$ & $(8)$ \\
\hline $\ln$ ROA (1) & \multicolumn{1}{|c|}{1} & & & & & & & \\
\hline $\ln$ ROE (2) & 0.567 & 1 & & & & & & \\
\hline $\operatorname{lnBoaDSIZE~(3)~}$ & -0.188 & -0.056 & 1 & & & & & \\
\hline $\operatorname{lnBoaDCOMP(4)}$ & 0.268 & 0.108 & 0.578 & 1 & & & & \\
\hline CEOD (5) & 0.087 & 0.046 & 0.396 & 0.316 & 1 & & & \\
\hline $\operatorname{lnSIZE~(6)~}$ & -0.297 & 0.049 & 0.410 & -0.372 & -0.272 & 1 & & \\
\hline $\ln$ BoaDM (7) & -0.020 & 0.056 & 0.036 & -0.106 & 0.038 & 0.052 & 1 & \\
\hline $\ln$ LEVERAGE (8) & 0.002 & 0.278 & 0.012 & 0.076 & 0.093 & 0.022 & -0.095 & 1 \\
\hline
\end{tabular}

The correlation test results show that there is a negative correlation between board size variable (BoaBSIZE) of the company and our both different measure of the corporate performance (ROA and ROE) in line with Abderrazak ELLOUZE (2014) who also found a negative correlation between these variables. This negative correlation can be explained by the fact that board of directors is inefficient in its control role, which could be due to a non-adequate size of the board of directors. There is a positive correlation between the number of independent directors (BoaDCOMP) and the both different measures of firm's performance measures (ROA and ROE). We could explain this positive correlation by arguing that when the proportion of independent directors increase, firm's performance increase also because independent members have high experience in others companies board and also have more competency.

The duality of CEO has a positive correlation with both the firm's performance measures (ROA and ROE), that is in conformity with the stewardship theory which shows that when a same person plays dual function, it improve firm performance. There is a negative correlation between firm size (SIZE), board activity (BoaBM), and firm's performance when firm's performance is measured by ROA and this correlation become positive when firm's performance is measuring by ROE. The LEVERAGE variable has a positive correlation with the firm's performance. Our correlation table shows that correlation between our different independent variables is low, because the value of $r$ between them is below 0.8 , looking this we can see the is not multi-correlation. However 
considering the independent variables among themselves, we can see the level of correlation $(r=0.578)$ between BoaDCOMP and BoaDSIZE is not too far to $r=0.8$. Because of this strong correlation between both independent variables, we conducted a multi-collinearity test, to be sure if there is not a multi-collinearty problem.

\subsection{Results of multi-collinearity test}

The main purpose of this test is to verify if there is a multi-collinearity problem or to make sure there is not a multi-collinearity problem. In our case we are doing this test to be sure there is not the multi-collinearty problem because mainly it is one of the conditions of our model (OLS) and also because there is a considerable correlation between two of our independent variables.

Table 4: showing result of the diagnostic multi-collinearity

\begin{tabular}{|l|l|l|}
\hline VARIABLES & \multicolumn{1}{|c|}{ VIF } & TOLERANCE \\
\hline $\operatorname{lnBoaDSIZE}$ & 1.88 & 0.53 \\
\hline $\ln$ BoaDCOMP & 1.60 & 0.63 \\
\hline CEOD & 1.52 & 0.66 \\
\hline $\operatorname{lnSIZE}$ & 1.29 & 0.78 \\
\hline $\ln$ BoaDM & 1.04 & 0.96 \\
\hline $\ln$ EVVERAGE & 1.01 & 0.99 \\
\hline
\end{tabular}

Note: first column is the vif variance, and second column is tolerance

According to the multi-collinearity principle, there is multi-collinearity problem in the model when the sum of the VIF values of all independent variables is 10 or more. Therefore according to this principle we can conclude that there is no multi-collinearity problem in this modelbecause the sum of our independent variables VIF value is 8.34 which less than 10 . The VIF mean is 1.39 , with a maximum value of VIF $=1.88$ less than 10 and the minimum value of VIF is $1.01<10$.However, all of tolerance value are above 0.1 , there is no multi-collinearity in our model considering that, we can conclude that there is a linear combination of the dependent and independent variables of our model.

\subsection{Heteroskedasticity test}

One of the common test of heteroskedasticity is the white test, which conduct to the nonlinear and interactive effect on the error variance of the independent variables. We are doing this test because it is one of the condition test to use our model (OLS). Basing on the estimate of white's test, the model used the chi 2 compared to $5 \%$ significance level. In our case, the null hypothesis is accepted and therefore the problem of heteroskedasticity does not exist in the model because the result show that the Chi 2 is not significant at $5 \%$ confidence level.

\subsection{Results of the regression and analysis}

The regression results and interpretation are summarized in two steps in tables 5 and 6 representing results of the Ordinary Least Squares (OLS) model to analyze relationship between board characteristics and firm's performance of non-financial companies in Cote d'Ivoire over the period 2002-2016. Column ROA representing the results of the regression from equation (1) where firm's performance was measuring by ROA and column ROE represents regression results from equation (2) where firm's performance was measuring by ROE. It is essential to note that in all results, there are some points that do stand out and can be easily observed generally. Firstly, two of three directional variables are very significant to the dependent variables for the both regressions, and secondly firm size variable (SIZE) are strongly significant to the dependent variables in both regression.

Table 5: showing Regression Results of board structure on financial performance

\begin{tabular}{|l|l|l|}
\hline Variables & \multicolumn{1}{|c|}{ ROA } & \multicolumn{1}{|c|}{ ROE } \\
\hline Intercept & 4.3806 & -1.8611 \\
\hline $\operatorname{lnBoaDSIZE}$ & $0.1873(0.722)$ & $0.2264(0.339)$ \\
\hline $\operatorname{lnBoaDCOMP}$ & $-0.3208(0.085)^{* * *}$ & $0.2803(0.038)^{* *}$ \\
\hline CEOD & $0.1370(0.057)^{* * *}$ & $-0.1680(0.002)^{*}$ \\
\hline $\operatorname{lnSIZE}$ & $-5.3406(0.000)^{*}$ & $0.0942(0.031)^{* *}$ \\
\hline $\operatorname{lnBoaDM}$ & $0.0265(0.888)$ & $0.1042(0.453)$ \\
\hline $\ln$ LEVERAGE & $0.0066(0.896)$ & $-0.0088(0.000)^{*}$ \\
\hline R square & 0.3926 & 0.3742 \\
\hline Adjusted R square & 0.3714 & 0.3597 \\
\hline F-Statistic & 13.42 & 11.67 \\
\hline
\end{tabular}

Note: * significant level of $1 \%(\mathrm{p}<0.01), * *$ significant level of $5 \%(\mathrm{p}<0.05), * * *$ significant level of $10 \%(\mathrm{p}<0.1)$, It is worth pointing out that the analysis of the results of table 5 shows the statistical non-nullity of the constant. 
This suggests that there are other(s) variable(s) with potential influence on company performance. The observation of the results shows that our dependent variable ROA and ROE variation are respectively explained at $37.14 \%$ and $35.97 \%$ by our independent variables in view of the value of adjusted $R$ square which is equal to 0.3714 and 0.3597 respectively. The results found from both equations (1) and (2) with dependent variables ROA and ROE reveal that, the number of board independent members (BoaDCOMP), duality of the CEO (CEOD), firm size (SIZE) and debt ratio (LEVERAGE) have statistical significant relationship with firm performance. It can be seen that although board size has a positive coefficient but does not significant, which means that a big board size has a positive relationship with firm performance (ROA and ROE). This finding is in accordance with the finding of Payal (2017) in one study on India CNX Nifty companies for a period 2012-13 to 2014-15. This implies that the size of the board does not add potential value to these companies and therefore cannot potentially affect firm performance (ROA and ROE). This may be explained by the fact that the board of directors does not make it possible to absorb environmental uncertainty and take the most favorable transactions. We find that as several previous studies that board size had a positive relationship with firm's performance (ROA and ROE).

Board of directors independence (BoaDCOMP) has a positive significant impact on return on equity $(\beta=$ 0.2803 , with $\mathrm{p}<0.05$ ). The positive significant relationship implies that the presence of independent directors significantly contributes to improve the performance ROE of companies. This result support agency theoretical framework of the study and validated our hypothesis 2 by reflecting what which is advocated in the literature. These independent directors improved the company performance with technical expertise and privileged environmental information to enhance its performance ROE. It appears that they are recruited for their skills and the independence of the board is an effective means for the control of the leaders. Therefore, their independence front of the leaders allows them to oppose the most questionable decisions. This finding is in accordance with the results of Baysinger \& Bulter (1985). By opposition to agency theory and our assumption 2 (H2), board of directors independence (BoaDCOMP) has a negative significant impact on firm's performance ROA because the independent directors variable show a negative coefficient and a significant $p$ value $(\beta=-0.3208, p$ value $=0.085$, $\mathrm{p}<0.1$ ). This implies that when the number of independent directors (BoaDCOMP) is great, consequently the performance ROA of the firm is poor. This negative significant relationship between the independent of the board of directors and firm's performance (ROA) can be confirmed with previous studies finding such as Ebrahim Mohammed Al-Matari (2012) in Kuwaiti and Haniffa \& Hudaib (2006) in Malaysia. The possible explanation for this finding is that the independent directors are external to the company, so they do not have enough information about company and therefore they cannot provide company with their technical expertise. According to that, board independence is an ineffective way of controlling directors.

According to the stewardship theory which states that whenever the CEO also acts as chairman, the company's performance increases due to the fact that the CEO of the company is relatively familiar and more desirous of raising capital (Williamson, 1985), CEO duality (CEOD) is positively significant with performance ROA. We find that the duality of the CEO had a significant positive effect on the company's performance (ROA), at the level of significance of $0.1(\beta=0.1370$, with $\mathrm{p}<0,1)$. This finding does not validated our hypothesis (H3) which is said that there is a negative relationship between CEO duality and company performance but support stewardship theoretical framework in our study. We can interpret this result by saying that this positive significant impact indicates that companies performance (ROA) increases when the chairman of the board takes the position of chief executive officer. This result is consistent with those found by Bhagat \& Black (2002), Yermack (1996) who investigated the relationship between CEO duality and company performance, respectively in the United States and Pakistan. The reasons for this result could be that the CEO appropriately exploits his experience within the company and his very specific knowledge of it, which can be useful for decision-making and subsequently increase his performance. By supporting agency theory, the cumulative of the duties of the Chairman of the board and the Chief Executive Officer (CEOD) is statistically negative and significant in relationship with companies performance ROE. The results obtained showed a negative relation between CEO duality (CEOD) and the performance (ROE) of the companies. This result can be explained by the fact that the manager does not properly exploit his experience within the company and his very specific knowledge of it, which can be useful for decisionmaking and subsequently increase his performance. In general, the combination of functions by the CEO conducts to a confusion of the responsibilities of the board Chairman and the Chief Executive Officer in the event of poor performance of the companies. So, considering this result, it is recommended to separate the two functions. This finding are empirically validated our hypothesis $3(\mathrm{H} 3)$ and reflect what which is advocated in the literature.

The results show that the size of the company (SIZE) has a positive and significant impact on the company's performance $(\mathrm{ROE})(\beta=0.0942$, with $\mathrm{p}<0.05)$. This positive sign indicates that, a large size of the company improve potentially his performance. In a previous study, (Klapper, 2003) found that the size of the company affected positively and significantly its performance. This could explained our results by the fact that when company size is large, it influences market, companies have more chance to diversify its activities, its product range and the company has many creation sources value. The results show that the size of the company (SIZE) has a negative and significant impact on the company's performance $(\mathrm{ROA})(\beta=-5.3406, \mathrm{p}<0.01)$. The negative sign 
indicates that, large is the size of the company, less is its performance. In a previous study, (Roman Horváth, 2012) found that the size of the company affected negatively and significantly its performance. This could be the case since when the company is large, it is often difficult to work on the projects of greatest impact, very difficult to do something new because it has very strict lines to follow about the creation collateral and this negatively impacts the performance of this one.

Regarding the number of board meetings and the leverage effect, the results obtained showed that these two variables do not significantly impact the performance of companies measured by ROA. We can note that even if the leverage had a negative relationship, it is insignificant on the ROA, while the number of board meetings (BoaDM) had a positive relationship but not significant on the ROA. The activity of the board of directors, measured by the number of its meetings, does not contribute significantly to the performance of the companies (ROE) but contributes positively. The possible explanation for this positive relationship could be explain by the fact that a large number of board meetings could create financial value for it, so improve his performance, because a significant number of board meetings generate an important supervising activity and control by leads to a convergence of interests between managers and shareholders. Finally, the results also showed that the debt ratio (LEVERAGE) of companies have a significant negative effect on the non-financial companies performance ROE $(\beta=-0.0088$, with $p<0,01)$. This result implies that the increase of the company's leverage reduces its performance (ROE). This finding is in consistent with the reported of Bohren (2005), by show that the higher is the debt ratio (LEVERAGE), the lower is the ROE. We could explain that by the fact that Cote d'Ivoire financial market is anew less efficient and the companies are high debt because they are trying to meet their pay higher interest rates and therefore this increase the cost of operations.

\subsection{Results of the robustness test and analysis}

We doing robustness test to capture the relevant of the significance relationship between our core variables and the dependent variables, to confirm the significant level of our core variables and also to confirm the nature of the impact of the independent variables on the dependent variables found with OLS regression model.

Table 6: showing Robust Regression Results

\begin{tabular}{|l|l|l|}
\hline Variables & \multicolumn{1}{|c|}{ ROA } & \multicolumn{1}{c|}{ ROE } \\
\hline $\operatorname{lnBoaDSIZE}$ & $0.1873(0.740)$ & $0.2265(0.390$ \\
\hline $\operatorname{lnBoaDCOMP}$ & $-0.3208(0.064)^{* * *}$ & $0.2803(0.035)^{* *}$ \\
\hline CEOD & $0.1371(0.060)^{* * *}$ & $-0.1680(0.001)^{*}$ \\
\hline $\operatorname{lnSIZE}$ & $-5.3406(0.001)^{*}$ & $0.0942(0.102)$ \\
\hline $\operatorname{lnBoaDM}$ & $0.0265(0.888)$ & $0.1042(0.472)$ \\
\hline $\operatorname{lnLEVERAGE~}$ & $-0.0066(0.897)$ & $0.0088(0.001)^{*}$ \\
\hline R square & 0.3926 & 0.3742 \\
\hline
\end{tabular}

Note: $*$ significant level of $1 \%(\mathrm{p}<0.01), * *$ significant level of $5 \%(\mathrm{p}<0.05), * * *$ significant level of $10 \%(\mathrm{p}<0.1)$

From the results of robust regression and OLS model regression, the estimation is relatively robust because the coefficients are plausible and robust, therefore the interpretation is thatour main analysis with the OLS methodology is right and the structure is valid. Indeed, from robust regression results, on considering dependent variable-ROA, our first core variable (BoaDSIZE) is not significant but has a positive coefficient such as in our model regression results (OLS). The others two core variables (BoaDCOMP and CEOD) are significant a 10 percent level for the both regression and have respectively negative coefficient and positive coefficient like with our regression model. On considering Dependent variable-ROE, first core variable (BoaDSIZE) has a positive coefficient but is not significant in both regression. The variables (BoaDCOMP and CEOD) have respectively positive coefficient and negative coefficient in both regression and also like in our regression model, are significant at 5 percent for BoaDCOMP and at 1 percent for CEOD.

\subsection{Additional tests}

In order to choose the best module to perform regression, we first did fixed and random effects regression for the two equations ( 1 and 2 ) and used the results of hausman specification test to test the fixed effects module and the random effects module. The results indicate that the fixed effects module is a better option when we measure our dependent variable by ROA (equation 1), because the result of hausman test, prob $>$ chi $2=0.0001$ is small than 0.05 , which implied the acceptance of the alternative hypothesis (Ha: the fixed effect is appropriate) and the rejection of the null hypothesis. When the dependent variable is measured by ROE (equation 2), the results indicate that the random effects module is a better option because the result of Hausman test, prob $>$ chi $2=0.1153$ is greater than 0.05 , which implies the acceptation of the null hypothesis (H0: the random effect is appropriate) and the rejection of alternative hypothesis. 
Analyzes of developed economies are an example for developing economies countries and more a road map for poor countries to the development. However the analyzes of the economies of developing or poor countries constitute a diagnostic and motivation to better lead these countries' economies to the development. In this section, we compare our study results to previous studies results. This comparison highlights the heterogeneity of the results on this topic that might be explained by different contexts of study. This comparison also shows the relevance of our direction variables on the performance. Specifically, we compare our results to those of some authors who have conducted their studies in 3 different countries (USA, France, and Tunisia) using the same key variables like in our study.

Table 7 summarizes the above mentioned comparison when the performance is measured by the return on assets (ROA) as well as the decisions of the authors while Table 8 summarizes the comparison when performance is measured by return on equity (ROE) with also the authors' decisions. We used the following hypotheses:

H1. Board size has a positive relationship with corporate performance

H2. Board of directors' independence has a positive relationship with corporate performance

H3. CEO duality has a negative relationship with corporate performance

Table 7: Summary of comparison of the author's major findings with performance ROA

\begin{tabular}{|c|c|c|c|c|}
\hline Country/Period & Authors & Hypothesis & Major Findings & Decisions \\
\hline $\begin{array}{l}\text { USA } \\
2001-2003\end{array}$ & $\begin{array}{l}\text { HoussenRachdi\& } \\
\text { Moez EL Gaied } \\
(2009)\end{array}$ & $\begin{array}{l}\mathrm{H} 1 \\
\mathrm{H} 2 \\
\mathrm{H} 3\end{array}$ & $\begin{array}{l}\text { Negative Not } \\
\text { significant } \\
\text { Positive Significant } \\
\text { Positive Significant }\end{array}$ & $\begin{array}{l}\text { Not supported } \\
\text { Supported } \\
\text { Not } \\
\text { Supported }\end{array}$ \\
\hline $\begin{array}{l}\text { FRANCE } \\
\text { 2002-2009 }\end{array}$ & $\begin{array}{l}\text { MohamedKadria\& A. } \\
\text { ELLOUZE } \\
(2014)\end{array}$ & $\begin{array}{l}\mathrm{H} 1 \\
\mathrm{H} 2 \\
\mathrm{H} 3\end{array}$ & $\begin{array}{l}\text { Positive Significant } \\
\text { Negative Significant } \\
\text { Positive Significant }\end{array}$ & $\begin{array}{l}\text { Not } \\
\text { Supported } \\
\text { Not } \\
\text { Supported } \\
\text { Not } \\
\text { Supported }\end{array}$ \\
\hline $\begin{array}{l}\text { TUNISIA } \\
1990-2004\end{array}$ & $\begin{array}{l}\text { Ghazi LOUIZI } \\
\text { (2006) }\end{array}$ & $\begin{array}{l}\mathrm{H} 1 \\
\mathrm{H} 2 \\
\mathrm{H} 3\end{array}$ & $\begin{array}{l}\text { Positive Significant } \\
\text { Positive Significant } \\
\text { Positive Significant }\end{array}$ & $\begin{array}{l}\text { Supported } \\
\text { Supported } \\
\text { Not } \\
\text { Supported }\end{array}$ \\
\hline $\begin{array}{l}\text { COTE } \\
\text { D'IVOIRE } \\
\text { 2002-2016 }\end{array}$ & Study findings & $\begin{array}{l}\mathrm{H} 1 \\
\mathrm{H} 2 \\
\mathrm{H} 3\end{array}$ & $\begin{array}{l}\text { Positive Not } \\
\text { significant } \\
\text { Negative Significant } \\
\text { Positive Significant }\end{array}$ & $\begin{array}{l}\text { Supported } \\
\text { Not } \\
\text { Supported } \\
\text { Not } \\
\text { Supported }\end{array}$ \\
\hline
\end{tabular}

According to comparison tables, we can say that the results change from one country to another for the performance. Indeed this variation has been explained by the authors in the study of each country.

Table 8: Summary of comparison of the authors major findings with performance ROE

\begin{tabular}{|c|c|c|c|c|}
\hline Country/Period & Authors & Hypothesis & Major Findings & Decisions \\
\hline $\begin{array}{l}\text { USA } \\
2001-2003\end{array}$ & $\begin{array}{l}\text { HoussenRachdi } \\
\text { \&Moez EL Gaied } \\
(2009)\end{array}$ & $\begin{array}{l}\mathrm{H} 1 \\
\mathrm{H} 2 \\
\mathrm{H} 3\end{array}$ & $\begin{array}{l}\text { Negative Not significant } \\
\text { Positive Significant } \\
\text { Positive Significant }\end{array}$ & $\begin{array}{l}\text { Not Supported } \\
\text { Supported } \\
\text { Not Supported }\end{array}$ \\
\hline $\begin{array}{l}\text { FRANCE } \\
2002-2009 \\
\end{array}$ & $\begin{array}{l}\text { MohamedKadria\& } \\
\text { A. ELLOUZE } \\
(2014) \\
\end{array}$ & $\begin{array}{l}\mathrm{H} 1 \\
\mathrm{H} 2 \\
\mathrm{H} 3 \\
\end{array}$ & $\begin{array}{l}\text { Negative Significant } \\
\text { Positive Significant } \\
\text { Negative Significant }\end{array}$ & $\begin{array}{l}\text { Supported } \\
\text { Supported } \\
\text { Supported } \\
\end{array}$ \\
\hline $\begin{array}{l}\text { TUNISIA } \\
1990-2004\end{array}$ & $\begin{array}{l}\text { Ghazi LOUIZI } \\
\text { (2006) }\end{array}$ & $\begin{array}{l}\mathrm{H} 1 \\
\mathrm{H} 2 \\
\mathrm{H} 3\end{array}$ & $\begin{array}{l}\text { Positive Significant } \\
\text { Positive Significant } \\
\text { Positive Significant }\end{array}$ & $\begin{array}{l}\text { Supported } \\
\text { Supported } \\
\text { Not Supported }\end{array}$ \\
\hline $\begin{array}{l}\text { COTE } \\
\text { D'IVOIRE } \\
2002-2016\end{array}$ & Study findings & $\begin{array}{l}\mathrm{H} 1 \\
\mathrm{H} 2 \\
\mathrm{H} 3\end{array}$ & $\begin{array}{l}\text { Positive Not significant } \\
\text { Positive Significant } \\
\text { Negative Significant }\end{array}$ & $\begin{array}{l}\text { Supported } \\
\text { Supported } \\
\text { Supported }\end{array}$ \\
\hline
\end{tabular}

\section{Conclusion}

The main objective of this thesis is to study the impact (relationship) of the board of director's characteristics on the performance of non-financial companies in Cote d'Ivoire over the period from 2002 to 2016. To carry out well our study, we measured our dependent variables which is the performance of the companies in two ways: ROA (Return on Asset) and ROE (Return On Equity). The characteristics essentially retained in our study are the size of the board, the independence of the board members and the duality of duties by the CEO. While conducting our 
study, we put forward the roles of control and monitoring as the role of the board of directors.

For a relevant explanation of the performance of these companies, we introduced three control variables in our study such as company size, the number of board meetings in the fiscal year, and the debt-to-equity ratio of the company for each fiscal year during our study period, 2002-2016. The data used in this study are quantitatively relative to the variables of the study and were collected on the website of the regional stock exchange of Abidjan, Cote d'Ivoire (BRVM) and on the websites of these companies for some years. However, within our previous empirical reading, we have noted that the results of these earlier studies are different and contradictory sometimes in terms of impact of the board's characteristics on the company's performance. In addition, the majority of these studies were conducted in developed countries, as well as developing countries in Asia and Europe, but few in African developing countries. The studies on the relationship between board and performance are very few or almost non-existent in Côte d'Ivoire.

Overall, some results have showing a positive relationship but are not statistically significant like the results of the impact of board size on firm's performance for all two performance measurement indicators in this study. These first results are in accordance with our hypothesis 1 and then support the results of Manme Kaur and Madhuvij (2017). On the other hand, the results of the impact of the number of independent administrators and the impact of the cumulative of functions confirm our hypotheses (H2 and $\mathrm{H} 3$ ) when firm's performance is measured by ROE, but are contradictory at the same time to our assumptions ( $\mathrm{H} 2$ and H3) when firm's performance is measured by ROA. In fact, our study results concerning the independence of the board of directors and its association with the performance of non-financial companies in Cote d'Ivoire lead to different and even contradictory conclusions depending on the measure of performance. Indeed, the results of many studies show that the proportion of independent directors contributed significantly to improve performance such as in our case when the performance is measured by ROE like Dr. Simranjit Singh (2017) in India. While the performance measured by ROA is deteriorate when the number of independent administrators increases and consistent with Khan's (2013) conclusion in Pakistan. So it can be said that the independent administrators have a significant impact on the performance of non-financial companies in Cote d'Ivoire, regardless performance measure. However, the conclusion relative to Duality of the CEO in this study is also different and contradictory to our assumption on the combination of the CEO's function when the performance is measured by ROA, and responds exactly and significantly to the stewardship theory like Bhagat in 1999. But contrarily to the case of first measure, when the performance is measured by ROE, the effect of the cumulative function becomes negative and this confirms our hypothesis 3 (H3) and the arguments of the theory of agency on this question. In view of these two sub-conclusions, it should be retained that the combination of the functions of CEO and Chairman of the Board of Directors has a significant impact on performance of the non-financial companies in Cote d'Ivoire, regardless performance measure.

Like any research this study suffers from some shortcomings which should specify them. Indeed we noted the limitations of sample size related to the availability of data, of the particular focus on non-financial companies. Therefore it is impossible to generalize our results to the financial sector. So in order to generalize the results to all sectors, another study could increase the sample size by considering the financial sectors by integrating others board features such as institutional directors, number of women on the board of directors, woman chairman of the board of directors and stock market performance proxy.

\section{Appendix}

Table A1: variables notation and measurement

\begin{tabular}{|l|l|l|l|}
\hline Variables & Symbol & Measurement proxy & Expect sign \\
\hline Board Size & BoaDSIZE & Logarithm of total number of directors & Positive \\
\hline Board Composition & BoaDCOMP & $\begin{array}{l}\text { Number of independent directors divided by the total } \\
\text { number of directors }\end{array}$ & Positive \\
\hline CEO Duality & CEOD & Value1 if duality is there, otherwise 0 & Negative \\
\hline Firm Size & SIZE & Logarithm of total assets & Positive \\
\hline Board activity & BoaDM & Logarithm of the number of directors meeting & Positive \\
\hline Leverage & LEVERAGE & Total debt divided by equity & Positive \\
\hline Return On Assets & ROA & Net income divided by total assets & Not \\
\hline Return On Equity & ROE & Net income divided by equity & Not \\
\hline
\end{tabular}


Table A2: Abbreviations and Acronyms

\begin{tabular}{|l|l|}
\hline OECD & Organization for Economic Co-operation and Development \\
\hline IFM & International Monetary Found \\
\hline OHADA & $\begin{array}{l}\text { Organisation pour l'Harmonisation en Afrique du Droit des Affaires } \\
\text { (Organization for the Harmonization of Corporate Law in Africa) }\end{array}$ \\
\hline BRVM & Bourse Regionale des Valeurs Mobiliere (securities stocks exchange) \\
\hline
\end{tabular}

\section{References}

Abderrazak Ellouze, Aymen Ammari, Mohamed Kadria. (2014) Board Structure and Firm Performance: Evidence from French Firms Listed in SBF 120. International Journal of Economics and Financial Issues Vol. 4, No. 3, 2014, pp.580-590.

Abidin, Z. Z.; Kamal, N.M. and Jussoff, K. (2009). Board structure and Corporate Performance in Malaysia. International Journal of Economics and Finance, Vol.1 No.1, 150-164.

Adams, R. B., Almeida, H., and Ferreira, D.(2005). Powerful CEOs and their Impact on Corporate Performance. Review of Financial Studies, Vol.18 No.4, 1403-1432.

Adams, R.B. and Mehran, H. (2003). Is Corporate Governance different for Bank Holding Companies? Economic Policy Review, Vol. 9 No.1, 123-142.

AfzalurRashid. (2010). CEO duality and firm performance: evidence froma developing country. Corporate ownership \& control / vol 8, issue 1, fall 2010, continued -1 .

Agrawal, A. and Knoeber. C. (1996). Firm Performance and Mechanisms to Control Agency Problems between Managers and Shareholders. Journal of Financial and Quantitative Analysis, Vol. 31 No.3, 377-397.

Aguilera, R. V. and Jackson. G. (2003).The Cross-National Diversity of Corporate Governance: Dimensions and Determinants. The Academy of Management Review, Vol. 28, No. 3, 447-465.

Rashid; De Zoysa, A.; Lodh, S.; and Rudkin, K., (2010) Board Composition and Firm Performance: Evidence from Bangladesh, Australasian Accounting, Business and Finance Journal, 4(1), 76-95.

Arslan, O., Karan, M.B., and Eksi, C. (2010).Board Structure and Corporate Performance. Managing Global Transitions, Vol 8. No.1, 3-22.

Baysinger, B. D., \& Butler, H. N. (1985). Corporate governance and the board of directors: Performance effects of changes in board composition. Journal of Law, Economics, \& Organization, 1(1), 101-124

Benjamin Ouedraogo Nosseyamba and Gérard Tchouassi. (2011). corporate governance and maximization of shareholder value: Theoretical analysis from Francophone countries in Africa. Journal of Public Administration and Policy Research Vol. 3(6), pp. 198-206.

Berkman, H., Cole, R.A. and Fu, J.L. (2009).Expropriation through Loan Guarantees to Related Parties: Evidence from China. Journal of Banking and Finance, Vol.33 No. 1, 141-156.

Bhagat, S. and Black B. (1999). The Uncertain Relationship between Board Composition and Firm Performance. The Business Lawyer, Vol. 54, 921-963.

Black, B., Jang, H., and Kim, W. (2006). Does Corporate Governance Predict Firms' Market Values?: Evidence from Korea. Journal of Law, Economics and Organization, 22, 366-413.

Brickley, J.A.; Coles, J.L. and Jarrell, G. (1997). Leadership Structure: Separating the CEO and Chairman of the Board. Journal of Corporate Finance, Vol.3 No.3, 189- 220.

Cadbury, S.A. (2000, January). The Corporate Governance Agenda. Corporate Governance, 8(1).

Chen, S. K., Wang, Y. P., Lin, B. X. and Wu, L. S. (2010). The Frequency and Magnitude of Earnings Management: Time-Series and Multi-threshold Comparisons. International Review of Economics \& Finance, Vol.19 No.4, 671-685.

Cho, D.S. and Kim, J. (2007).Outside Directors, Ownership Structure and Firm Profitability in Korea. Corporate Governance: An International Review, Vol.15, No.2, 239-250. http://dx.doi.org/10.1111/j.14678683.2007.00557.x

Chugh, L.C.; Meador, J.W. and Kumar, A.S. (2011). Corporate Governance and Firm Performance: Evidence from India.Journal of Finance and Accounting, Vol. 7, 1-11.

Clifford, P. and Evans, R. (1997). Non-Executive Directors: A Question of Independence. Corporate Governance: An International Review, Vol.5, No.4, 224-231.

Coles, J. W., McWilliams, V. B. and Sen, N. (2001).An Examination of the Relationship of Governance Mechanisms to Performance, Journal of Management, 27.

Core, J.E., Holthausen, R.W., and Larcker, D.F. (1999). Corporate governance, chief executive officer and firm Performance. Journal of Financial Economics, 51, 371-406. http://dx.doi.org/10.1016/S0304-405X (98)00058-0.

Davis, J.H, Schoorman, D. and Donaldson, L. (1997).Toward a Stewardship Theory of Management. Academy of Management Review, Vol. 22, No.1, 20-47.

Donaldson, L. and Davis, J. (1991). Stewardship Theory or Agency Theory: CEO Governance and Shareholder 
Returns. Australian Journal of Management, Vol.16, No. 1, 49-64.

Drobetz, W., Felix V. M., David Oesch, and Markus Schmid (2013). Is Director Industry Experience a Corporate Governance Mechanism? Working paper, University of Hamburg.

Dr.SimranjitSingh,Payal. (2017). Board of Directors and Corporate Performance: Evidence from India. Envision - International journal of commerce and management. VOL-11, No.62481, 2456-4575.

Ebrahim Mohammed Al-Matari, Abdullah Kaid Al-Swidi, FaudziahHanimBtFadz. (2012). The Impact of board characteristics on Firm Performance: Evidence from Nonfinancial Listed Companies in Kuwaiti Stock Exchange. International Journal of Accounting and Financial Reporting. Vol.2, No.2, 2162-3082.

Erickson, J., Park, Y. W., Resing, J., and Shin, H.H. (2005). Board composition and Firm Value under Concentrated Ownership: The Canadian Evidence. Pacific-Basin Finance Journal, Vol.13, 387 -410. http://dx.doi.org/10.101/j.pacfin.2004.11.002

Estes, R.M. (1980). Corporate Governance in the Courts. Harvard Business Review, Vol. 58, 50-58.

Fama, E.F. and Jensen M.C. (1983). Separation of Ownership and Control, Journal of Law and Economics, Vol. 26, 301-325.

Fatma Tifafi, Dominique Dufour. (2006). Une analyse de la présence d'administrateurs indépendants au sein du conseil d'administration : contrôle ou conseil ?.comptabilité, contrôle, audite institution(s), may 2006, Tunisie. pp. Cd-rom, 2006. < Halshs-00558255>.

Finkelstein, S., and D'Aveni, R. A. (1994). CEO Duality as a Double-edged Sword: How Boards of Directors Balance Entrenchment Avoidance and Unity of Command. Academy Management Journal, Vol. 37, No. 5, $1078-108$.

Forbes, D.P. and Milliken, F. (1999). Cognition and Corporate Governance: Understanding Board of Directors as Strategic Decision-Making Groups. Academy of Management Review, Vol.24, No.3, 489-505.

Ghazi Louizi. (2006) impact du conseil d'administration sur la performance des banques tunisiennes. XVème Conférence Internationale de Management Stratégique, Annecy / Genève 13-16 Juin 2006

Hermalin, B. and Weisbach, M. (2001). The Effects of Board Composition and Direct Incentives on Firm Performance. Financial Management, Vol. 20, 101-112.

Hermalin, B.E. and Weisbach, M.S. (2003). Boards of Directors as an Endogenously Determined Institution: A Survey of the Economic Literature. Economic Policy Review, Vol.9, No.1, 7-26.

Houssem Rachdi et Moez El Gaied. (2009). L'Impact de l'Indépendance et de la dualité du Conseil d'Administration sur la Performance des Entreprises : Application au Contexte Américain. Revue Libanaise de Gestion et d'Economie | No 3, 2009.

Hsu, H. (2010). The Relationship between Board Characteristics and Financial Performance: An Empirical Study of United States IPO. International Journal of Management, Vol.27,No.2, 332-341.

Ibtissem Chouchane. (2010), «Les déterminants de la présence des administrateurs indépendants dans les conseils d'administration des sociétés françaises», La Revue des Sciences de Gestion 2010/5 (n²45-246), p. 63-71. DOI 10.3917/rsg.245.0063.

Jackling, B. and Johl, S. (2009). Board Structure and Firm Performance: Evidence from India's Top Companies. Corporate Governance: An International Review, Vol.17 No.4, 492-509.

Jensen, M. C. (1993). The Modern Industrial Revolution, Exit, and the Failure of Internal Control Systems. The Journal of Finance, Vol.48, No.3, 831-880. http://dx.doi.org/10.1111/j.1540-6261.1993.tb04022.xM.

Jensen, M., and Meckling, W. (1976). Theory of the Firm; Managerial Behaviour, Agency Costs and Ownership Structure. Journal of Financial Economics, 305-360.

Khanna, Tarun and Krishna, G. Palepu (2004). Globalization and Convergence in Corporate Governance: Evidence from Infosys and the Indian Software Industry. Journal of International Business Studies, Vol. 35, No. 6, 485-506.

Klein, A. (2002). Audit Committee, Board of Director Characteristics, and Earnings Management. Journal of Accounting and Economics, Vol.33 No.3, 375-400.

Koudou Zohoré Olivier. (septembre 2013) L'influence des mécanismes de gouvernance sur la performance des institutions de micro finance de la Côte d'Ivoire. "Gouvernance et management» V èmes Journées Internationales de la Micro finance sur le thème: « Mutations et Crises de la micro finance », Douala, 11, 12 et 13 Septembre 2013.

Kumar, N. and Singh, J. P. (2013). Effect of Board Size and Promoter Ownership on Firm Value: Some Empirical Findings from India. Corporate Governance, Vol. 13 No (1), 88-98. http://dx.doi.org/10.1108/14720701311302431

Lipton, M. and Lorsch, J.W. (1992).A Modest Proposal for Improved Corporate Governance. The Business Lawyer, Vol. 48, No.1,

Lorsch, J.W. and MacIver, E. (1989). Pawns or Potentates: The Reality of America's Corporate Boards, Harvard Business School Press, Boston, MA.Mcconomy, B. J. and Bujaki, Merridee L. (2000). Corporate Governance: Enhancing Shareholder Value. CMA Management, Vol. 47 No.8, 10-13. 
Millstein, I. (1992). The Limits of Corporate Power: Existing Constraints on the Exercise of Corporate Discretion. Macmillan, New York, NY.

Mintzberg, H. (1983). Power in and around Organizations. Englewood Cliffs, NJ: Prentice Hall.

O’Sullivan, N. (2000). The Determinants of Non-Executive Representation on the Boards of Large UK companies. Journal of Management and Governance, 4, 283-297.

Rajagopalan, N. and Zhang,Y. (2009). Recurring Failures in Corporate Governance: A Global disease? Business Horizons, Vol.52, No.6, 545.

Rechner, P. L. and Dalton, D. R. (1991). CEO Duality and Organizational Performance: A Longitudinal Analysis. Strategic Management Journal, Vol.12, 155-160.

Roman Horváth, Persida Spirollari. (2010). do the board of directors' characteristics influence firm's performance? The U.S. evidence. DOI: 10.18267/j.pep.435

Rose, C. (2005). The Composition of Semi-two-tier Corporate Boards and Firm Performance. Corporate Governance: An International Review, Vol.13, No.5, 691-701. http://dx.doi.org/10.1111/j.14678683.2005.00460.x.

Rosenstein, S. and Wyatt, J.G. (1990). Outside Directors, Board Independence and Shareholder Wealth. Journal of Financial Economics, Vol. 26, 175-191.

Sarkar J, (2009). Board Independence and Corporate Governance in India: Recent Trends and Challenges Ahead. Indian Journal of Industrial Relations, Vol. 44, No.4, 554 -575.

Sarkar, J. and Sarkar, S. (2009). Multiple Board Appointments and Firm Performance in Emerging Economies: Evidence from India. Pacific-Basin Finance Journal, Vol.17 No.2, 271-293. 